\title{
Developing a monograph book for teaching English skills to young learners in wetlands
}

\section{areas}

\author{
Dini Noor Arini ${ }^{1 *}$ \\ Raisa Fadilla ${ }^{2}$ (D) \\ 1,2English Language Education, University Lambung Mangkurat, Banjarmasin, Indonesia
}

\begin{abstract}
To enable Universitas Lambung Mangkurat (ULM) to become the Asia-Pacific centre for wetlands development in 2027, one of the efforts ULM makes is to raise awareness about the importance of optimising human resources in wetlands through research and development in the educational and cultural fields. English is considered a foreign language in Indonesia, allowing students to use the language outside of academic settings. English becomes a required subject in junior and senior high school; however, the government requires that English be taught in primary schools as a local topic. English, on the other hand, remains a mandatory subject in a large number of Indonesian primary schools, particularly in Banjarmasin. The issue arises in primary school English instruction because there is no clear guidance for teachers on how to teach English in an appropriate and engaging manner for the students. Due to the absence of a monograph book on teaching methods, teachers in some primary schools in Banjarmasin, particularly those located in wetland areas, have limited access to teaching English to young learners (EYL). In light of the university's policy and the critical nature of achieving teaching and learning objectives, as well as the absence of a suitable reference book for teaching EYL, this study aims to develop an appropriate monograph book on teaching techniques for students of young ages. The research and development design is chosen because it aims to create a product and meets the needs of the reference book's development. The results are expected to improve students' academic performance and to assist EYL teachers in wetland areas in conducting effective and meaningful teaching.
\end{abstract}

\section{KEYWORDS}

English Teaching; young learners; wetland areas

Received: 8 November 2021 Accepted: 15 November 2021 Published: 16 November 2021

\section{Introduction}

English is widely used in Indonesia as a foreign language in various industries, including education, business, politics, technology, and so on. English is taught at all stages of education, from kindergarten to university, because of the desire to master English as a communication tool. One of the most effective strategies to master English is to begin learning it at a young age. Many people feel that the sooner people learn a language, the faster it will be to master it. According to Marinova-Todd (2003), age influences second language proficiency (L2). Furthermore, according to (Brown, 2001), the Critical Period Hypothesis (CPH) supports the idea that language acquisition is more straightforward between the age of two and early adolescence. It's also worth noting that language instruction should begin at a young age (Singleton \& Ryan, 2004).

There are several advantages for people when they start to learn English at a young age. According to (Johnstone, 2009; Paradis, 2004), children who have a strong interest in learning language, particularly the sound system, and who have elaborated implicit knowledge (information kept unconsciously) have a strong interest in learning a language. They are better at producing the target language's sounds and rhythms, but they are not as good at creating the target language's emotion. Children also have a strong sense of intuition and are less self-conscious. They also devote significantly more time to learning new languages and have a greater capacity for developing intercultural awareness.

Consequently, children who begin learning at a young age may have more opportunities to develop and enhance their skills. As a result, the belief that 'the younger, the better' can be accurate because younger learners learn better, and more prolonged exposure leads to more experience after the learning process (Enever \& Moon, 2009). McCloskey 
(2002) stated that in teaching English for Young Learners, several principles need to be known by the teachers. The first is that the teaching and learning process should provide learners with engaging and active learning opportunities. It then uses multi-dimensional and thematically grouped exercises to help students learn and practice the language through collaboration. Furthermore, utilizing scaffolding, vocabulary development, and an active approach, teachers should deliver comprehensible input. It's also vital to execute language integration with content and validate and merge home language and culture. Finally, teachers should set clear objectives and provide timely feedback.

English is considered a foreign language in Indonesia, so students have limited opportunities to use it outside of academic settings such as schools and courses. English in Indonesia is taught from primary school until secondary school. In junior and senior high school, English becomes a compulsory subject to be taught; however, in elementary school, English is designated as a local content-a topic that is not required to be trained-by the government. As a result of this strategy, many primary schools, particularly public ones, omit English from the curriculum. This issue, on the contrary, does not support the fundamental theory stating the importance and advantages of learning English from an early age. Consequently, the students at younger generations rarely use the language with their surroundings. The key to mastering English is implementing what they have learned actively as possible in real life.

Even though English is classified as one of the local subjects, English remains a compulsory subject in numerous Indonesian elementary schools, particularly in Banjarmasin. Furthermore, at some places, English begins to be taught at the kindergarten level. However, the problem arises in teaching English for young learners since there is no clear guidance for the teachers on teaching English appropriately and interestingly for the students at that level. Moreover, the teachers in some primary schools in Banjarmasin, especially in wetland areas such as Bantaran Sungai, have limited access to teaching English for young learners since the unavailability of reference literature regarding the teaching techniques for teaching EYL. Referring to university policy to enable ULM to become the center of Asia-Pacific wetlands development in 2027, one of the efforts that ULM conducts is to promote the awareness of optimizing the human resources in wetlands by doing research and development in the educational and cultural field. Concerning the university's policy and seeing the importance of achieving the teaching goals, learning process, and lack of suitable reference book for teaching English for young learners; henceforth, this study is intended to develop an appropriate monograph book related to teaching techniques to teach English for students at young ages not only to improve EYL students' academic performance but also to facilitate EYL teachers in wetland areas to conduct effective and meaningful teaching in wetland areas.

The purpose of this study is to develop a monograph related to the technique of teaching English language skills (listening, reading, speaking, and writing) with the topic of wetland learning for young learners that meets the needs of English for teachers of young learners in wetland areas in Banjarmasin, especially in the Riverbanks to equip students with meaningful and effective teaching and learning process.

\section{Literature review}

\section{Teaching English to young learners}

Teaching English to Young Learners refers to teaching English to children in pre-or primary school who do not speak the language natively. It comprises children whose first language is not English but rather their country's national language, with English serving as a second language. Early English language acquisition was so prevalent that no matter how good the reasons were; they would have little bearing on whether or not English was taught. The active process of training youngsters at school is known as early language learning. Given this, we should instead concentrate on researching the circumstances of early language development to enhance procedures so that both children and teachers have positive language experiences both within and outside the classroom. The well-documented increase in the number of youngsters studying English at a younger age worldwide is one explanation for the spike in interest (Garton et al., 2011; Johnstone, 2009). Another conclusion is that research done with older students and adults may not apply to young students who are still developing cognitively and emotionally. There is also recognition that globalization, and the resulting mobility of people worldwide, create new learning environments, particularly for children. Finally, as academics debunk several common misconceptions concerning young language learners, such as that it is better to start learning a language early or that children cannot learn two languages simultaneously, the focus is shifting to how children learn languages. These characteristics, when combined, have resulted in a golden moment in which the young learner and the young learner classroom have received clear and consistent attention.

It is often assumed that childhood is the optimum age to begin learning a second or foreign language. Because children's native languages evolve throughout childhood, it's reasonable to assume that they are better adapted to absorb languages than their elders and that they can learn a second or foreign language more rapidly and readily. In addition, observation of toddlers and adults learning a new language supports the notion that learning a second language is more accessible when you're younger. As an example, we may occasionally witness a young immigrant child mastering a completely effective command of the host country's language while functioning as an interpreter 
for his parents. Not to mention that very young tour guides are capable of mastering a variety of foreign languages (Singleton \& Pfenninger, 2019).

Young learners share short attention spans and a holistic approach to learning but differ in terms of their physical, psychological, social, emotional, cognitive, and social development. Ellis (2014) proposes labels for the various age groups based on terminology commonly used in the educational systems to which children belong. Although the age ranges covered by the term young learners vary depending on a country's educational system, Ellis (2014) proposes labels for the various age groups based on terminology frequently used in the educational systems to which children belong. Preschoolers, often known as pre-primary students, are youngsters aged two to five years' old who are referred to as very young learners or early beginnings. Primary school students are referred to as young learners; secondary school students are referred to as young learners or early teens if they are between the ages of eleven and fourteen, and those between the ages of fourteen and sixteen are referred to as young learners or early teens if they are between the ages of fourteen and sixteen. In this chapter, I will concentrate on children aged 6 to 11.

Teacher Education (TED) refers to the training and professional development opportunities available to instructors both before and during their careers as teachers, referred to as pre-service and in-service teacher education, respectively. As a result, Teacher Education (TED) encompasses both planned and unexpected learning opportunities that may occur both within and outside the classroom (Rich, 2018). Right now, the growing need for English Language Teacher Education (ELTED) is rapidly increasing in many sectors, including in government and institutional planning of regulation. Part of the highlight attention given in English Language Teacher Education is rooted in a growing understanding of the crucial role it plays in accelerating quality of teachers that is widely acknowledged as the core factor in giving students the aid to accomplish their objective in learning (Enever, 2014; Hattie, 2003). Furthermore, this development also reflects the broader expansion and reform of English language instruction worldwide in encouraging and producing competent teachers and their effective approaches in class and student development. Significantly, for the belief that teachers' access to their professional development opportunities will serve as a critical point in the success of education innovations (Wedell, 2009).

One of the most significant improvements in English Language Learning that has lately occurred is the reduction of the students' age at which English Language Learning can begin or be facilitated. In many countries, English education is a standard part of the primary school curriculum, and it is increasingly being given to younger and younger students, with current estimates indicating that a majority number of instructors are working in the field of English for Young Learners. Consequently, it is not surprising news that policymakers and researchers are rapidly showcasing the importance of developing a teacher workforce to work with young learners (especially in primary schools). Not only that but it is also proven to be urgent to provide provision for teacher education (Rich, 2018).

\section{Teaching English to young learners in wetlands context}

In reading, it is essential to provide a connection for the student's interaction with the text and their interaction with the author. For example, the majority of individuals believe that reading focuses on how to derive meaning from the text. In the class context, students can comprehend the meaning of the text and build a connection to it. They will try to connect the text by relating the written material with their own real-life experience and background knowledge. This basic knowledge is described as Schema. In context, when students comprehend the story of Kancil dan Buaya, they are reflecting their knowledge or schema of animals to the image of the story. This is the way they can understand the story better. Thus, this reading activity can be viewed as a collaborative effort between the reader or the students, the text/story, and the author.

Aside from reading, writing is also classified as a collaborative effort that entails some consideration of the reader or person who will be reading the content. It is the unwritten obligation for writers to decide and to consider their readers before executing what to write and how to express it. These considerations also affect students on their writing of vocabulary or word choice, grammar, and mechanics (such as spelling and punctuation). Besides that, the consideration also includes tone, style in writing, and many other aspects like the category of the target audience. The creation of a dynamic relationship between the reader and the author through text demands the learning of several skills.

In creating all types of texts, young EFL learners need to have a variety of skills. Modeling the skills and techniques that pupils need to employ is one strategy to help young learners increase their reading and writing skills. For example, in the read-aloud, the teacher shows the students how to read smoothly and expressively while enjoying the reading. Previewing could also be implemented in the class, where students are guided to focus on visuals, headings, and other highlight elements to forecast what will happen in the text. In the process, they can also be taught how to identify text structures, such as the beginning, how the middle is formulated, and where the story is finished. These are some of the abilities that teachers can portray to the students (Shin, 2017). As for the children at the lower level or who require extra help in understanding the foundations of writing in English, teachers can alternatively start with something simple by providing enjoyable and short writing activities, such as copying and unscrambling words 
and sentences, or by facilitating gap-filling game activities. Teachers can also use the style of writing 'think-aloud where students are directly explaining their reasoning while writing the text on a whiteboard or a chart. Meanwhile, for the advanced young learners, a teacher could try practicing with a brainstorm to generate ideas, define the purpose for the work, and creatively create a graphic organizer like a table or chart to help formulate structured text and even paragraph writing.

As for listening skills, it is often referred to as the receptive use of language. It is the process of employing speech context and one's knowledge of language to interpret the meaning of the communications. Listening which is a hearing process is positively contributing some vital input for other language abilities such as speaking and writing to run smoothly (Linse, 2005; Rost, 2002). Listening is a difficult skill to master because it involves listeners deciphering the meaning of spoken passages, storing the input of information in the long-term memory of the brain, and producing the end mean of message or interpretations (Richards, 2008). Thus, it can be said that listeners must be active participants and information processors. As stated by (Cameron, 2001), these cases are also applicable towards listeners from young learners, they have to analyze and evaluate information from auditory and some visual cues to define the meaning.

Last, but not least, speaking skill is the active use of language to express meaning as a productive language skill. Speaking entails expressing thoughts, opinions, or a desire to act, as well as forming social bonds and friendships (McDonough \& Shaw, 2003). For most young learners, speaking is the primary means of encountering, understanding, practicing, and learning a new language. Speaking achievement of students even can be shown as evidence of learning for the instructor. Thus, listening and speaking are inextricably linked, especially in the classroom for young learners.

\section{Methods}

Dealing with the aim of this research is developing a monograph book related to teaching techniques for teaching English skills for young learners in wetland areas, the appropriate design for this research is research and development (R\&D). Borg et al. (2007) depict educational research and development as a process to develop and validate educational products. It also appears to be the most promising strategy for improving education. Research and development was chosen because this type of research aims to develop a product and covers the needs when creating materials or books.

\section{Need analysis}

Need analysis is used for gathering data as the foundation to design the monograph book of teaching techniques of English skills of EYL teachers in wetland areas. The objective in conducting needs analysis is to examine the existing materials and determine what the teachers need for teaching English for young learners. Therefore, a need analysis survey was conducted to teachers who teach English in wetland areas to meet the criteria and needs to be determined in this study.

\section{Participants}

Participants of this study were 10 English teachers from 10 primary schools located near Martapura river, one of the longest rivers in South Kalimantan.

\section{Instruments}

This research employed questionnaires to gather data on need analysis to ensure the needs of the teachers and students towards appropriate teaching techniques for young learners.

\section{Research procedure}

The model of research and development is adapted from (Borg et al., 2007) due to the accessibility and feasibility. The procedure of this study includes (1) conducting need analysis, (2) developing the monograph book, (3) designing and conducting formative evaluation, (4) revising the book, and (5) conducting summative evaluation or product try-out.

\section{Results}

In the development results, the results found during development are explained which consist of the results of needs analysis, product design, product development, product evaluation, and final product. 


\section{Results of need analysis}

Firstly, a needs analysis was conducted to determine the needs of primary school English teachers in the wetland area in Banjarmasin related to the teaching techniques of wetland materials. Then, researchers distributed questionnaires to 10 teachers from 10 schools. This was done to obtain specific information about teaching techniques for young learners related to wetland material. The results of the questionnaire are used as the basis for developing the product.

From the needs analysis results, it can be seen that teachers have various preferences regarding effective ways for students to learn wetland materials. Six teachers suggested that reading books related to wetlands might be an effective way to learn English related to wetlands. Furthermore, reading articles from the internet can help students study wetland materials effectively. Likewise, listening to audio recordings and watching videos related to wetlands will positively impact young students because these media are considered exciting and interactive. Interestingly, most teachers (80\%) disagreed that listening to traditional South Kalimantan songs would increase students' knowledge of wetlands. As one of the aspects taught in English, writing English words and also translating them into the first language-related to wetlands is considered an acceptable way of learning about wetlands (60\%). Surprisingly, $70 \%$ of teachers stated that making observations in wetlands is not necessary to improve English language learning about wetlands. In speaking skills, teachers (80\%) agree that having discussions in class and asking questions about wetlands will be an effective way to learn English related to wetlands. Researchers considered all these preferences in developing the product.

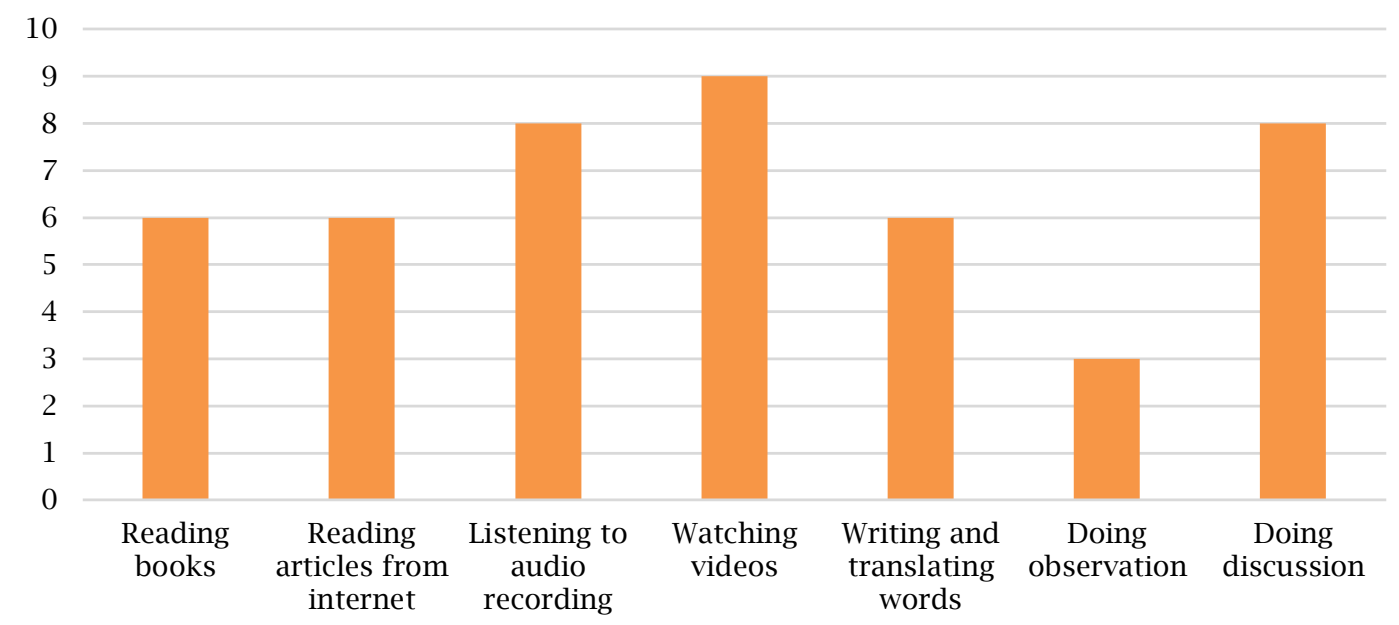

Figure 1. Teaching activities preference

For the topics required for teaching English using wetland materials, most of the teachers stated that primary school students need to learn the types and characteristics of wetlands. As part of the wetland community, topics on the social life of wetlands and the value and function of wetlands are also raised. Furthermore, students feel the needto-know wetland habitat and wetland conservation. Threats to wetlands are also important to teach as a wetland teaching topic.

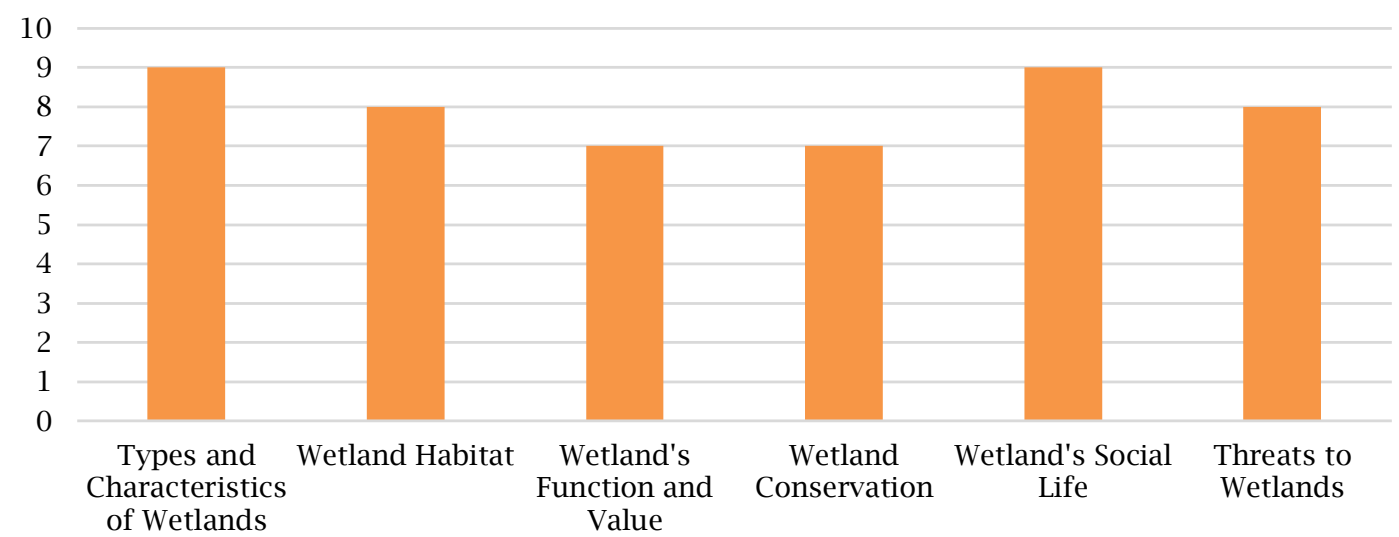

Figure 2. Topics preferred for teaching wetlands to young learners 
Several points can be concluded from the needs analysis; First, it is vital to provide references to teaching techniques for teaching wetlands that suit their preferences and needs. Second, it is important to develop and design a monograph in which teaching topics related to wetlands are included based on teacher preferences. Based on these points, the researcher decided to create a reference for teaching English skills for early childhood in wetland areas in the form of a monograph.

\section{Results of product design}

Before developing the product, the researcher designed the product based on the result of needs analysis. In this product design stage, there were two major steps to do. They were planning the product and making the blueprint.

The first step was planning. In this stage, the researcher made a plan which was later used as the basis for making a blueprint of the product. The plan was made by defining the techniques based on teachers' preferences from the results of need analysis and also from the English skills which are listening, reading, speaking, and writing. Thus, the researcher took the result of needs analysis which involve the topics preferred for teaching wetlands and the activities preferred to teach wetlands. Then, constructing a blueprint of the product was conducted. In the blueprint, the learning topics and specific teaching techniques are mentioned. The considerations of choosing the techniques are from the need analysis conducted. However, to suit the students' level and ability, the teaching techniques were specifically chosen and modified by the researcher to meet the criteria of teaching English for young learners.

Table 1. Blueprint of the product

\begin{tabular}{ll}
\multicolumn{1}{c}{$\begin{array}{c}\text { Topics preferred for teaching } \\
\text { wetlands }\end{array}$} & \multicolumn{1}{c}{$\begin{array}{c}\text { Teaching techniques for teaching English skills for } \\
\text { young learners }\end{array}$} \\
\hline Types and Characteristics of & - English Subtitled of Wetlands Short Clips \\
Wetlands & - Bottom-up Technique \\
& - Descriptive Technique in Writing \\
& - Presentation Technique \\
& - Information Gap \\
& - Summarizing \\
\hline Wetland Habitat & - Matching Words to Pictures Technique \\
& - Guessing Games \\
& - Know Want Learn \\
& - What's Missing? \\
& - Three Phase Technique \\
\hline Wetland's Function and Value & - Group Work Technique \\
& - Process Approach \\
& - Semantic Mapping \\
& - Discussion \\
& - Clustering \\
\hline - Imitative Writing \\
- Dialogue Techniques for Grammar and Vocabulary \\
Teaching \\
- Storytelling \\
- Extensive Reading \\
- Number Head Together \\
- Situational Learning Listening \\
- Extensive Monologue \\
- Mind-mapping \\
- Ticking-off Item \\
- Charades \\
\hline - Speaking Class through Debate \\
- Group Work \\
- Discussion \\
- Competency-Based Language Teaching \\
- Fishbowl Technique \\
\hline Wetland's Social Life & \\
&
\end{tabular}

\section{Results of product development}

The result of the development of the product was a set of products which was in form of a monograph book about teaching English skills for young learners in wetland areas. The monograph book was developed based on topics preferred by the teachers and the techniques chosen were from the need analysis. There were six topics developed in 
the monograph book; types and characteristics of wetlands, wetland habitat, wetland's function, and value, wetland conservation, wetland's social life, and threat to wetlands.

The development of the product was done through a series of steps. After the blueprint had been made in the product design stage, the monograph book was developed. The materials related to teaching techniques were taken from many sources including books and online sources by adopting and adapting. After finding the appropriate teaching techniques, the researcher designed how the teaching techniques are presented in the monograph book.

The next step was designing the product. The main product in this study is the monograph book that discusses the teaching techniques for English skills for young learners in wetland areas. The materials related to teaching techniques include an introduction, procedures of the technique, how to implement them in teaching and learning activities, and advantages of the technique. To make the monograph book attractive and interesting, the researchers used some figures and colors.

\section{Results of product evaluation}

The product validation from an expert in teaching English to young learners and a book designer was included in the product review. After the product had been confirmed and validated by professionals, the adjustment and the revision were made.

After finishing the draft of the product, it was evaluated by the expert of teaching English for young learners and the expert of book design. The expert of teaching EYL and the expert of book design were given a form to fill in. The first aspect is about teaching English for young learners which include the relevancy between the objectives of teaching and the teaching techniques, the relevancy between skills and techniques, and the clarity of the procedures and the implementation. The expert of book design was in charge of validating the book cover, the type and style of letters, book layout, and overall design and appearance of the monograph book.

The average score for all judgments given by the expert of teaching English for young learners and the expert of book design was $89.08 \%$ meaning that the monograph book was feasible to use. The expert in teaching EYL emphasized the various use of four English skills throughout the book. As for the book design, the expert validator stated that the illustration of the cover was attractive yet simple. However, the writing format including the font of the writing should be redesigned to make it more attractive and clearer.

\section{Final product}

After the draft was evaluated and revised, the product was developed entirely. The product functions as a reference for EYL teachers when teaching English skills in wetland areas. The product is in the form of a monograph book entitled Teaching English Skills for Young Learners in Wetland Areas.

The monograph book provides various teaching techniques which are arranged based on topics. The topics are types and characteristics of wetlands, wetland habitat, wetland's function, and value, wetland conservation, wetland's social life, and threat to wetlands. The teaching techniques are presented based on the topic. For types and characteristics of wetlands, the techniques chosen are English subtitled of wetlands short clips, bottom-up technique, a descriptive technique in writing, presentation technique, information gap, and summarizing. For wetland habitat, the techniques are matching words to pictures technique, guessing games, Know Want Learn (KWL), What's Missing? and three-phase technique. For wetland's function and value, the techniques are group work technique, process approach, semantic mapping, discussion, and clustering. For wetland conservation, the techniques are imitative writing, dialogue techniques for grammar and vocabulary teaching, storytelling, extensive reading, and number head together. For teaching wetland's social life, the techniques are situational learning listening, extensive monologue, mind-mapping, ticking-off item, and charades. Lastly, for teaching threat to wetlands, the appropriate techniques are speaking class through debate, group work, discussion, competency-based language teaching, and fishbowl technique.

Each technique presented in the monograph book begins with the overview of the skills taught using the technique, procedures of the technique, how to implement in teaching and learning activities, and advantages of the technique. Moreover, it is also completed with figures to make the description of the techniques clearer. The references are also provided for the readers in every technique described. The monograph book was designed with attractive font size and engaging typing style to make it easy for teachers to read.

\section{Discussion}

The result of this study is a monograph book for English for Young Learner teachers in wetland areas, especially in Bantaran Sungai. This monograph book is entitled Techniques in Teaching English Skills for Young Learners in Wetland Areas. The product is believed to be able to fulfill the needs found in the need analysis. The problems found are the lack of materials regarding teaching English skills for young learners, especially in wetland areas. Thus, this developed product is expected to help the teachers prepare the student's teaching and learning activity. 
The monograph book has been designed, it was further validated, to obtain valid material (content and teaching aspects). This is in line with Emzir (2010), who argues that validation is the process of product design assessment done by giving a rating based on rational thinking. In this study, the validation is performed by two experts according to their expertise. Based on the validity by experts, online wetland materials developed is a very valid category with 90.05\% and $88.11 \%$ of validity. Riduwan (2012) stated that the range of value interval of 81 - 100 is a very valid category. Based on these values, the monograph book can be completed as a final product.

According to expert validation and try-out results, this final developed product is positively relevant and applicable for teachers to teach English skills to young learners in wetland areas. Teachers will find the instructional strategies presented in the created product as appealing, contextual, and relevant. Following the statement by (Cameron, 2001; Lorenz \& Met, 1989) that it is essential for children's successful language learning that the learning experience takes place in a genuine context with authentic materials (Edelenbos et al., 2006). This idea is also follows Shin's statement that young learners like movement and physical engagement the most if the teacher can provide an enjoyable full environment, the students will more likely to retain and restore the language they have learned (Shin, 2006).

This product provides the instruction for teachers to implement the teaching techniques based on wetlandrelated topics. Knowledge about wetlands in Kalimantan Selatan is essential to be included in English subjects from an early age. Knowledge about wetlands influences behaviour connected to their protection (Mwakubo \& Obare, 2009; Yim \& J, 2009) and a lack of understanding is commonly associated with their destruction. The objective of Education for Sustainable Development (2005-2014) initiated by UNESCO, required educational institutions to step up their contributions to prepare students for a sustainable future. Furthermore, the product is also presented with figures for any teaching technique so that the teachers can understand the implementation of the technique.

Aside from the aforementioned beneficial aspects of the product, there are a few drawbacks. The product is developed to be used only in wetland areas. Additionally, only a few games are presented as teaching techniques in the monograph book. It is important to provide a lot of games as the techniques for teaching EYL as stated by (Yolageldili \& Arikan, 2011) that the existence of games in the classroom is significantly needed for entertainment and relaxation purposes, and also for the crucial benefit in facilitating students to express themselves in creative and communicative manners.

\section{Conclusion}

Based on the results of the research, it can be concluded that there is no clear guideline for primary school teachers on how to teach English that is appropriate and attractive to students in wetland areas. Moreover, they have limited access to teaching English for children due to the unavailability of resources on teaching techniques. Seeing the importance of achieving teaching and learning objectives and the lack of appropriate references for teaching English to children, the development of appropriate books related to teaching techniques of teaching English to children is very necessary. Through some phases of activities that have been carried out, this study produced a monograph book for teachers related to techniques of teaching English skills for young learners in wetland areas. Development activity in this study starts with conducting need analysis, developing the monograph book, formulating and implementing the formative evaluation, revising the book, and conducting the summative evaluation. The study results show that the monograph book is positively applicable to be implemented in teaching English for young learners.

\section{Acknowledgments}

We would like to express enormous appreciation to our support system and those who made valuable suggestions or who have otherwise contributed to the preparation of the paper. Without their continuing support, cooperation, and encouragement this research paper would not have been written and published.

\section{Funding}

We would like to express our gratitude to Lembaga Penelitian dan Pengabdian kepada Masyarakat (LPPM), Lambung Mangkurat University for funding our research in the scheme of Madya Cluster PDWM (Penelitian Dosen Wajib Meneliti) funded by PNBP 2021.

\section{References}

Borg, W. R., Gall, M. D., \& Gall, J. P. (2007). Educational Research (7th ed.). New York: Longman. 
Brown, H. D. (2001). Teaching by Principles: An Interactive Approach to Language Pedagogy. San Fransisco: Addison-Wesley Longman Inc.

Cameron, L. (2001). Teaching Languages to Young Learners. Cambridge: Cambridge University Press.

Edelenbos, P., Johnstone, R., \& Kubanek, A. (2006). The Main Pedagogical Princi- ples Underlying the Teaching of Languages to Very Young Learners. Final Report of the EAC 89/04, Lot 1 study. Brussels: European. commission.http://ec.europa.eu/education/policies/lang/doc/young_en.pdf

Ellis, G. (2014). Young learners": Clarifying our terms. ELT Journal, 68(1), 75-78.

Emzir. (2010). Metodologi penelitian pendidikan:kuantitatif dan kualitatif. Jakarta: Rajawali Pers.

Enever, J. (2014). Primary English teacher education in Europe. ELT Journal, 6(3), 231-242.

Enever, J., \& Moon, J. (2009). New Global Contexts for Teaching Primary ELT: Change and Challenge. ELT: Change and Challenge.

Garton, S., Copland, F., \& Burns, A. (2011). Investigating Global Practices in Teaching English to Young Learners. London: British Council.

Hattie, J. A. C. (2003). Teachers make a difference: What is the research evidence? Paper presented at the Australian Council for Educational Research Annual Conference on: Building Teacher Quality. Australian Council for Educational Research Annual Conference On.

Johnstone, R. (2009). An early start: What are the key conditions for generalized success? In J. Enever, J. Moon, \& U. Raman (Eds.), Young learner English language policy and implementation: International perspectives. In $J$. Reading: Garnet Education Publishing Ltd.

Linse, C. T. (2005). Practical English Language Teaching: Young learners. New York: McGraw-Hill.

Lorenz, E., \& Met, M. (1989). What It Means to Be An Immersion Teacher. Rockville, MD: Office of Instruction and Program Development, Montgomery County Public Schools.

Marinova-Todd, S. H. (2003). Comprehensive analysis of ultimate attainment in adult second language acquisition. Harvard University.

McCloskey, M. L. (2002). Principles for Teaching Young Learners of English. Home.Comcast.Net.

McDonough, J., \& Shaw, C. (2003). Materials and Method in ELT (U. K. Blackwell (ed.); 2nd ed.). Blackwell.

Mwakubo, S. M., \& Obare, G. A. (2009). Vulnerability, livelihood assets and institutional dynamics in the management of wetlands in Lake Victoria watershed basin. Wetlands Ecology and Management, 17, 613-626.

Paradis, M. (2004). A neurolinguistic theory of bilingualism. Amsterdam: John Benjamins.

Rich, S. (2018). Early Language Learning and Teacher Education. The Routledge Handbook of Teaching English to Young Learners. Oxon: Routledge Publication.

Richards, J. (2008). Teaching Listening and Speaking. New York: Cambridge University Press.

Riduwan. (2012). Skala pengukuran variabel-variabel penelitian. Bandung: Alfabeta.

Rost, M. (2002). Teaching and Researching Listening. London: Longman.

Shin, J. K. (2006). Ten helpful ideas for teaching English to young learners. English Teaching Forum, 44(2), 2-13.

Shin, J. K. (2017). Literacy Instruction for Young EFL Learners: A balanced approach. Boston, MA: National Geographic Learning.

Singleton, D., \& Pfenninger, S. (2019). The Age Debate. The Routledge Handbook of Teaching English to Young Learners. Oxon: Routledge Publication.

Singleton, D., \& Ryan, L. (2004). Language Acquisition: The Age Factor (C. M. Matters (ed.); 2nd ed.). Multilingual Matters.

Wedell, M. (2009). Planning for Educational Change: Putting people and their contexts first. London: Blackledge.

Yim, S., \& J, C. (2009). Farmers' perception of wetlands and their attitude on government wetlands policies. Journal of the Korean Geographical Society, 44, 624-633.

Yolageldili, G., \& Arikan, A. (2011). Effectiveness of Using Games in Teaching Grammar to Young Learners. Elementary Education Online, 10(1), 219-229. 